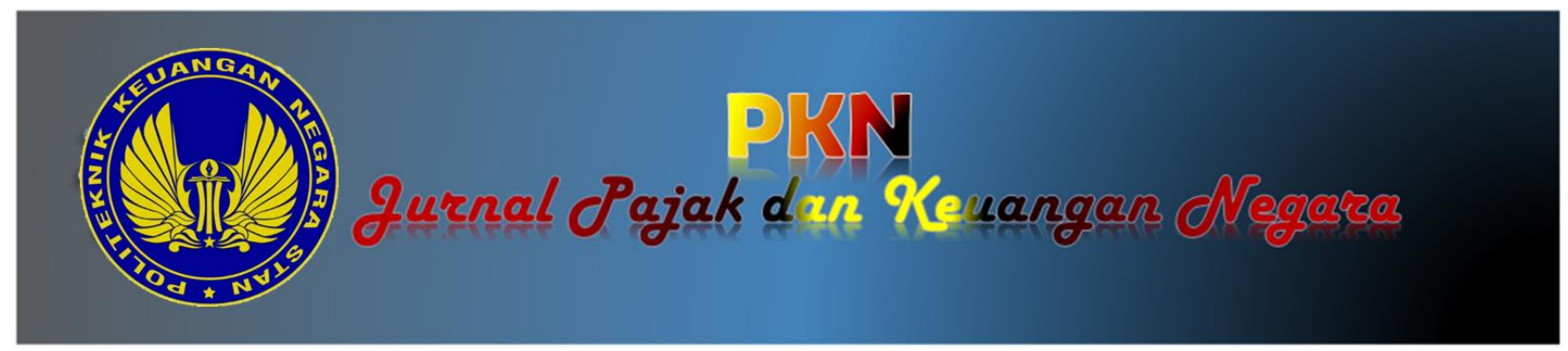

\title{
KEUNTUNGAN DAN KERUGIAN PENGGUNAAN METODE GROSS-UP DALAM PERHITUNGAN PPh PASAL 21 PEGAWAI TETAP MELALUI ANALISA PERBANDINGAN
}

\author{
Andri Marfiana \\ Politeknik Keuangan Negara STAN
}

Alamat Korespondensi: andri.marfiana@pknstan.ac.id

\section{INFORMASI ARTIKEL}

Diterima Pertama

[30 Agustus 2019]

Dinyatakan Diterima

[30 September 2019]

\section{KATA KUNCl:}

PPh Pasal 21, Metode Gross-Up, Ms Excel, Tax Planning, Tax.

KLASIFIKASI JEL:

$G-18, H-25$

\section{ABSTRACT}

This research aims to show a comparative between Gross-Up method with others method to calculate article 21 income tax in order to tax planning action. Moreover, this journal gives a tutorial, how to calculate Article 21 Income Tax, use Gross-Up method in Ms Excel and e-SPT aplication. This research uses descriptive and tutorial method to discuss research questions.

The result shows that the implementation of Gross-Up method in calculating article 21 income tax, only gives optimal result if implemented to employees who has salary below company tax rate. Contrary, the result will be minumum if used to employees who have higher tax rate. However, income tax benefit that give to employees can increase a motivation among them.

In this study, it is argued that the implementation of Gross-Up method can be optimal in situational cases.

\section{ABSTRAK}

Penelitian ini bertujuan memberikan perbandingan penerapan metode Gross-Up dengan metode lainnya untuk menghitung PPh Pasal 21 dalam rangka perencanaan pajak. Lebih lanjut jurnal ini memberikan panduan bagaimana melakukan perhitungan PPh Pasal 21 menggunakan metode Gross-Up pada aplikasi Ms Excel dan e-SPT. Penelitian menggunakan metode descriptive comparative dan panduan dalam membahas permasalahan penelitian.

Hasil penelitian menunjukan bahwa penerapan metode Gross-Up dalam perhitungan PPh Pasal 21 Pegawai Tetap hanya optimal apabila diterapkan kepada pegawai yang memiliki penghasilan pada lapisan tarif pajak dibawah tarif PPh Badan. Sedangkan apabila diterapkan pada pegawai yang terkena lapisan tarif pajak tertinggi, metode Gross-Up tidak memberikan manfaat bagi Wajib Pajak. Namun demikian pemberian insentif berupa Tunjangan Pajak, dapat memberikan motivasi bagi pegawai, karena tax home pay yang diterima tidak lagi dikurangkan oleh PPh Pasal 21.

Dalam penelitian ini, dapat disimpulkan bahwa penerapan metode Gross-Up akan optimal dalam situasi tertentu tergantung keadaan Wajib Pajak. 


\section{PENDAHULUAN}

\subsection{Latar Belakang e-SPT PPh Pasal 21/26}

Sadarkah kita bahwa efek pemanasan global semakin meningkat setiap tahunnya. Hal ini dapat kita rasakan dengan makin tingginya suhu udara hampir di semua belahan dunia. Tidak hanya itu, dampak lain yang ditimbulkan oleh pemanasan global antara lain: perubahan cuaca yang ekstrim, putting beliung, dan kekeringan (Susanta \& Sutjahjo, 2007). Salah satu penyebab pemanasan global adalah penggunaan kertas yang berlebihan. Hal ini dikarenakan kertas yang dihasilkan di produksi dengan cara menebang hutan-hutan produktif. Berkaitan dengan hal tersebut, mendorong beberapa organisasi baik pemerintah maupun swasta mulai beralih ke green computing.

Green computing adalah " penggunaan sumber daya komputer secara efisien dengan cara mengurangi penggunaan bahan-bahan berbahaya, memaksimalkan efisiensi energi selama umur produk, dan meningkatkan daur ulang serta biodegradasi bagi produk gagal dan limbah pabrik" (Yefta \& Muljadi, 2011). Termasuk dalam kategori green computing adalah penghematan penggunaan kertas dan memanfaatkan informasi teknologi. Atas dasar tersebut beberapa instansi pemerintah mulai melakukan hal tersebut, salah satunya adalah Direktorat Jenderal Pajak (DJP) Kementerian Keuangan.

Melalui Peraturan Menteri Keuangan nomor 9/PMK/2018 tentang Perubahan atas Peraturan Menteri Keuangan Nomor 243/PMK.03/2014 tentang Surat Pemberitahuan (SPT), diatur bahwa "SPT Masa PPh Pasal 21 dan/atau Pasal 26 dalam bentuk dokumen elektronik wajib digunakan oleh pemotong pajak, sepanjang pemotong pajak melakukan pemotongan PPh Pasal 21 dan/atau Pasal 26 terhadap subjek pajak yang jumlahnya lebih dari 20 (dua puluh) orang dalam 1 (satu) Masa Pajak". Pelaporan dalam bentuk dokumen elektronik tersebut, diproses melalui suatu aplikasi yang disediakan oleh DJP yang disebut e-SPT, dalam hal ini e-SPT PPh Pasal 21/26. Aplikasi inilah yang mengolah data Wajib Pajak (WP), menjadi bentuk Surat Pemberitahuan (SPT).

Data yang diolah oleh aplikasi e-SPT berbasiskan program-program Microsoft Office (MS Office), seperti MS Access dan Ms Excel. Penggunaan database berbasis Microsoft Office digunakan karena lazim digunakan oleh masyarakat umum. Akan tetapi pengaplikasian data dari MS Office untuk diimplementasikan ke dalam aplikasi $e$-SPT, tidak semua dimengerti oleh WP. Untuk itu salah satu tujuan dari penulisan ini adalah dalam rangka membantu WP dalam mengaplikasikan MS Office kedalam aplikasi e-SPT.

\subsection{Tujuan Penelitian}

Tujuan dari penelitian ini adalah memberikan panduan, bagaimana cara menghitung PPh Pasal 21 Pegawai Tetap menggunakan metode Gross-up dengan menggunakan aplikasi Ms Excel. Penghitungan PPh Pasal 21 menggunakan aplikasi Ms Excel ini menggunakan format yang disediakan oleh aplikasi e-SPT PPh Pasal 21/26. File ini nanti akan digunakan untuk di impor dengan format csV kedalam aplikasi e-SPT PPh Pasal 21/26.

Tujuan lainnya adalah mencoba menganalisa, penerapan metode gross-up terkait perencanaan pajak. Penelitian ini mencoba menjelaskan, seberapa besar manfaat yang diperoleh oleh Wajib Pajak dalam penerapan metode gross-up dalam penghitungan PPh Pasal 21 Pegawai Tetap. Manfaat ini akan berimbas juga kepada PPh Badan dari WP yang menerapkan metode ini. Pada bagian selanjutnya akan diterangkan mengenai kerangka teori dari penulisan ini.

\section{KERANGKA TEORI}

\subsection{Definisi $e$-SPT}

Dalam Pasal 1 butir 11 Undang-Undang Nomor 6 Tahun 1983 tentang Ketentuan Umum dan Tata Cara Perpajakan sebagaimana diubah dengan Undang-Undang Nomor 16 tahun 2009 (UU KUP) disebutkan bahwa "Surat Pemberitahuan yang selanjutnya disingkat SPT adalah surat yang oleh Wajib Pajak digunakan untuk melaporkan penghitungan dan/atau pembayaran pajak, objek pajak dan/atau bukan objek pajak, dan/atau harta dan kewajiban sesuai dengan ketentuan peraturan perundang-undangan di bidang perpajakan". Lebih lanjut Direktorat Jenderal Pajak mendefinisikan $e$ SPT sebagai "aplikasi yang dibuat oleh Direktorat Jenderal Pajak Kementerian Keuangan untuk digunakan oleh Wajib Pajak untuk kemudahan dalam menyampaikan SPT" (Kementerian Keuangan, 2019). Berdasarkan definisi tersebut, untuk memudahkan WP dalam menyampaikan SPT, DJP menyediakan aplikasi $e$-SPT. Aplikasi ini dapat diunduh di halaman resmi DJP dan disediakan secara gratis (Direktorat Jenderal Pajak, 2019). Salah satu jenis e-SPT yang dibahas dalam penelitian ini adalah e-SPT PPh Pasal 21/26.

e-SPT PPh Pasal 21/26 digunakan sebagai SPT Masa PPh Pasal 21/26 secara elektronik. SPT Masa ini melaporkan besarnya pemotongan PPh 
Pasal 21/26 sehubungan dengan pekerjaan, jasa, dan kegiatan orang pribadi sesuai dengan Peraturan Dire (PER16, 2016). Sampai dengan saat ini e-SPT PPh Pasal 21/26 yang terbaru adalah versi 2.4.0.0 tanggal 1 Desember 2016. Aplikasi ini dapat diunduh pada halaman https://www.pajak.go.id/id/e-spt-masa-pph-pasal21-26-versi-2400.

Dalam menggunakan e-SPT PPh Pasal 21/26, WP yang mempunyai karyawan dalam jumlah besar akan mengalami kesulitan apabila harus menginput data secara manual. Untuk itu e-SPT PPh Pasal 21/26 menyediakan fasilitas impor data yang memudahkan WP dalam memindahkan data pegawai kedalam database e-SPT PPh Pasal 21/26. File yang digunakan untuk transfer data dari file pegawai WP kedalam e-SPT PPh Pasal 21/26 adalah file cSV. CSV adalah "suatu format data dimana setiap record dipisahkan dengan koma (,) atau titik koma (;)" (Solichin, 2010). File ini dapat dibuka pada aplikasi Ms Excel dalam bentuk tabel dengan format khusus. Untuk itu tulisan ini membahas penggunaan fasilitas pada aplikasi Ms Excel dalam memudahkan WP mengisi e-SPT PPh Pasal 21/26 menggunakan metode gross-up.

\subsection{Metode Gross-up dan Iterative calculation}

Metode Gross-up dalam PPh Pasal 21 adalah cara penghitungan PPh Pasal 21 dengan cara menambah PPh Pasal 21 yang terutang sebagai tunjangan pajak, dimana hasil pajak yang terutang sama dengan besarnya tunjangan pajak (Ashriana, 2017). Sehingga pendapatan yang diterima oleh pegawai tetap tidak dikurangi oleh pajak, tetapi dibayar oleh perusahaan melalui tunjangan pajak. Untuk menghitung PPh Pasal 21/26 ini biasanya digunakan aplikasi Ms Excel. Untuk dapat menghitung metode gross-up pada aplikasi Ms Excel perlu diaktifkan fitur Iterative calculation.

Iterative calculation adalah fitur dalam aplikasi Ms Excel yang digunakan untuk melakukan penghitungan berulang, dimana hasil perhitungan menjadi sumber perhitungan (Microsoft, 2019). Dengan menggunakan fitur ini, penghitungan PPh Pasal 21 dengan menggunakan metode gross-up tidak akan menimbulkan pesan error. Hal ini disebabkan secara default, Ms Excel tidak dapat menghitung suatu formula dimana hasil penghitungan, kembali dijadikan salah satu sumber perhitungan. Dengan mengaktifkan fitur ini, Ms Excel akan secara otomatis menghitung kembali hasil perhitungan tanpa pesan error.

Dengan menggunakan kedua fasilitas tersebut, paper ini akan menggambarkan manfaat yang di dapat oleh WP dalam melakukan manajemen pajak. Manfaat metode ini juga berpengaruh kepada pegawai tetap yang memperoleh penghasilan dan juga penerimaan pajak bagi DJP.

\subsection{Manajemen Pajak}

Manajemen Perpajakan adalah "usaha menyeluruh yang dilakukan tax manager dalam suatu perusahaan atau organisasi agar hal-hal yang berhubungan dengan perpajakan dari perusahaan atau organisasi tersebut dapat dikelola dengan baik, efisien, dan ekonomis, sehingga memberi konstribusi maksimum bagi perusahaan" (Pohan, 2013). Melihat definisi tersebut pemanfaatan metode gross-up dan e-SPT PPh pasal 21/26 merupakan bagian dari manajemen pajak.

Berdasarkan teori yang ada, manajemen pajak mempunyai beberapa fungsi, antara lain: “perencanaan pajak (tax planning), pelaksanaan perpajakan (tax implementation), dan pengendalian pajak (tax control)" (Irawan \& Farahmita, 2012). Menurut Pohan (2013) tax planning adalah usaha yang mencakup perencanaan perpajakan agar pajak yang dibayar oleh perusahaan benar-benar effisien. Sedangkan tax implementation adalah melaksanakan kewajiban formal dan material sesuai ketentuan perpajakan yang berlaku, dan tax control adalah pengawasan manajemen untuk memastikan bahwa seluruh peraturan perpajakan telah dilaksanakan. Berdasarkan fungsi-fungsi yang ada, penggunaan metode gross-up untuk perhitungan PPh Pasal 21 Pegawai Tetap termasuk dalam fungsi tax planning. Penelitian tentang tax planning dengan metode gross-up sudah banyak dilakukan dan akan dibahas selanjutnya.

\subsection{Penelitian Terdahulu}

Banyak penelitian yang terdahulu membahas perencanaan PPh Pasal 21. Sebagai contoh, Nabilah (2016) menemukan bahwa penerapan metode gross-up pada perhitungan PPh Pasal 21 telah menurunkan jumlah PPh Badan yang harus dibayar dan meningkatkan laba komersial perusahaan. Lebih jauh, penelitian yang dilakukan pada salah satu perusahaan di Kabupaten Karang Asem menunjukan bahwa penggunaan metode gross-up pada PPh Pasal 21 telah meningkatkan laba setelah pajak (Earn After Tax) (Sahilatua \& Noviari, 2013). Selain itu, perbandingan penggunaan metode Net Basis dan Metode Grossup dalam perhitungan PPh Pasal 21 pada suatu perusahaan di Manado menunjukkan benefit bagi karyawan dan perusahaan dan juga meningkatkan motivasi karyawan dalam bekerja (Vridag, 2016). Penelitian-penelitian tersebut menunjukkan hasil 
yang positif bagi perusahaan dalam menerapkan Metode Gross-up dalam perhitungan PPh Pasal 21.

Bertentangan dengan penelitian yang disebutkan sebelumnya. Dalam penelitian lain di salah satu BUMN di daerah Tuminting Manado, penggunaan metode gross-up dalam penghitungan PPh Pasal 21 justru meningkatkan jumlah PPh Pasal 21 yang dibayar (Arham, 2016). Hasil yang serupa juga ditunjukan oleh penelitian yang dilakukan oleh peneliti lain. Farida, Alfian, and Cempaka (2016) menunjukan bahwa PPh Pasal 21 yang harus dibayar sebelum dan sesudah penerapan metode gross-up, belum cukup menguntungkan perusahaan. Atas dasar tersebut diatas, masih terdapat ruang untuk peneliti melihat apakah penggunaan metode gross-up dalam penghitungan PPh Pasal 21, terutama pegawai tetap, dapat dijadikan cara dalam perencanaan pajak.

Berdasarkan penelitian terdahulu yang menunjukkan hasil yang berbeda tersebut, tulisan ini akan membahas manfaat penggunaan metode gross-up dalam penghitungan PPh Pasal 21. Namun sebelumnya penulis akan memberikan panduan cara menghitungnya dengan aplikasi Ms Excel dan penerapannya pada e-SPT PPh Pasal 21/26. Sehingga adapun perumusan masalah dalam jurnal ini adalah:

1. Bagaimana panduan cara menghitung PPh Pasal 21 Pegawai Tetap dengan metode gross-up pada Ms Excel dengan memanfaatkan fitur Iteration Calculation;

2. Menganalisa deskriptif comparative antara metode gross-up dengan metode lainnya, dalam rangka perencanaan PPh Pasal 21 Pegawai Tetap;

3. Bagaimana panduan mengimpor data file csv PPh Pasal 21 Pegawai Tetap yang sudah mengandung metode gross-up kedalam e-SPT.

Metode penelitian pada tulisan ini akan dibahas pada bagian selanjutnya.

\section{METODE PENELITIAN}

Metode penelitian ini menggunakan metode penelitian descriptive comparative dan panduan. Descriptive comparative adalah metode penelitian yang membandingkan variable yang ada, dan menjelaskannya secara mendalam (Villanueva, 2019). Sedangkan menurut Kamus Besar Bahasa Indonesia, panduan adalah pengajaran tambahan dengan cara dibimbing (KBBI, 2019). Sehingga penelitian ini hanya akan membahas keuntungan dan kerugian penggunaan beberapa metode perhitungan PPh Pasal 21 Pegawai Tetap melalui analisa perbandingan. Lebih jauh pada jurnal ini penulis akan memberikan panduan penggunaan $e$ SPT PPh Pasal 21 kaitannya dengan data csV.
Dalam menganalisa perbandingan antar metode tersebut, penulis menggunakan aplikasi $M s$ Excel office 365 dalam melakukan perhitungan. Sedangkan untuk melakukan panduan, selain cara menggunakan Ms Excel, penelitian ini akan memberikan cara menggunakan e-SPT atas data yang sudah dianalisa tersebut melalui panduan. Cara ini digunakan karena aplikasi tersebut berhubungan dalam kewajiban perhitungan dan pelaporan PPh Pasal 21 oleh Wajib Pajak.

Data yang akan digunakan pada penelitian ini hanya bersifat simulasi dan bukan menggunakan data angka yang real. Akan tetapi angka yang digunakan dapat meggambarkan manfaat dan kerugian penggunaan metode perhitungan PPh Pasal 21 Pegawai Tetap. Hal ini dilakukan agar tidak ada pihak yang merasa dirugikan atas data yang disajikan dalam penelitian. Selain itu, data yang digunakan berupa nilai rupiah penghasilan, yang dikelompokan berdasarkan lapisan tarif pajak.

Metode perhitungan PPh Pasal 21 yang dipakai dalam penelitian ini sebagai bahan komparasi adalah metode gross-up (variable utama), metode gross, dan metode neto. Untuk definisi perhitungan gross-up sudah dijelaskan pada bagian kerangka teori. Sedangkan untuk pengertian metode gross adalah perhitungan PPh Pasal 21 dimana pajak yang terutang dipotong dari penghasilan karyawan. Sebaliknya, metode neto adalah perhitungan PPh Pasal 21, dimana pajak yang terutang ditanggung oleh perusahaan. Pembahasan Analisa dengan menggunakan metode ini akan dibahas pada bagian selanjutnya.

\section{HASIL PENELITIAN}

\subsection{Perhitungan PPh Pasal 21 Metode Gross-up}

Dalam melakukan perhitungan PPh Pasal 21 Pegawai tetap dengan menggunakan metode gross-up, tool yang digunakan adalah aplikasi Ms Excel. Untuk dapat menjalankan perhitungan dengan benar maka fitur iteration calculation perlu diaktifkan. Apabila fitur tersebut tidak diaktfikan maka akan menimbulkan pesan error dalam aplikas Ms Excel. Berikut adalah contoh apabila fitur iterative calculation tidak diaktifkan: 
Gambar 1

Gross-up Error

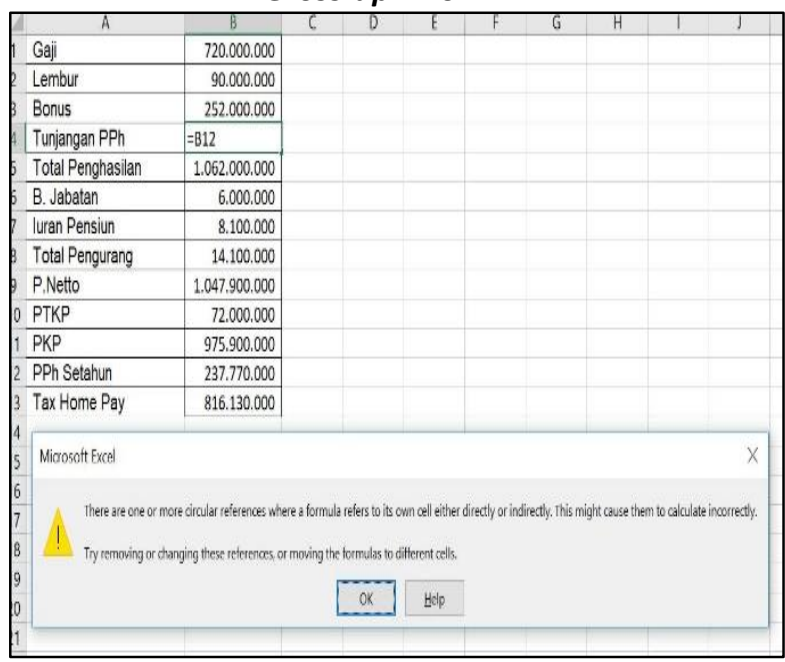

Pesan errornya berbunyi "there are one or more circular references where a formula refers to its own cell either directly". Pesan tersebut memberikan informasi bahwa satu atau lebih sumber perhitungan merujuk kepada hasil perhitungan itu sendiri. Akibat error tersebut perhitungan PPh Pasal 21 dengan metode gross-up pada aplikasi Ms Excel tidak dapat dilakukan. Ms Excel juga menginformasikan cell mana yang menjadi permasalahan dalam perhitungan, seperti ditampilkan pada gambar berikut:

\section{Gambar 2}

Cell Error

\begin{tabular}{|c|c|c|}
\hline$\triangle$ & A & B \\
\hline 1 & Gaji & 720.000 .000 \\
\hline 2 & Lembur & 90.000 .000 \\
\hline 3 & Bonus & 252.000 .000 \\
\hline 4 & Tunjangan $\mathrm{PPh}$ & $8 \quad-$ \\
\hline 5 & Total Penghasilan & 1.62 .000 .000 \\
\hline 6 & B. Jabatan & \begin{tabular}{l|l} 
& 6.000 .000 \\
\end{tabular} \\
\hline 7 & Iuran Pensiun & 8.100 .000 \\
\hline 8 & Total Pengurang & 14.100 .000 \\
\hline 9 & P.Netto & $1 . \$ 47.900 .000$ \\
\hline 10 & PTKP & \begin{tabular}{l|l}
72.000 .000 \\
\end{tabular} \\
\hline 11 & PKP & 75.900 .000 \\
\hline 12 & PPh Setahun & 37.770 .000 \\
\hline 13 & Tax Home Pay & 816.130 .000 \\
\hline
\end{tabular}

Dari Gambar 2 terlihat bahwa Tunjangan PPh yang merupakan sumber perhitungan menggunakan data dari hasil perhitungan. Sehingga Ms Excel tidak dapat melakukan perhitungan secara tepat.

Untuk dapat menggunakan metode perhitungan PPh Pasal 21 secara gross-up, sebenarnya Ms Excel menyediakan fitur khusus, yaitu iterative calculation. Fitur tersebut memungkinkan Ms Excel melakukan perhitungan ulang, apabila sumber perhitungan berasal dari hasil perhitungan itu sendiri. Untuk dapat mengaktifkan fitur tersebut, kita dapat membukanya di tab: File $\rightarrow$ Option $\rightarrow$ Formula $\rightarrow$ check enable iterative calculation. Untuk lebih jelasnya dapat dilihat pada gambar berikut ini:

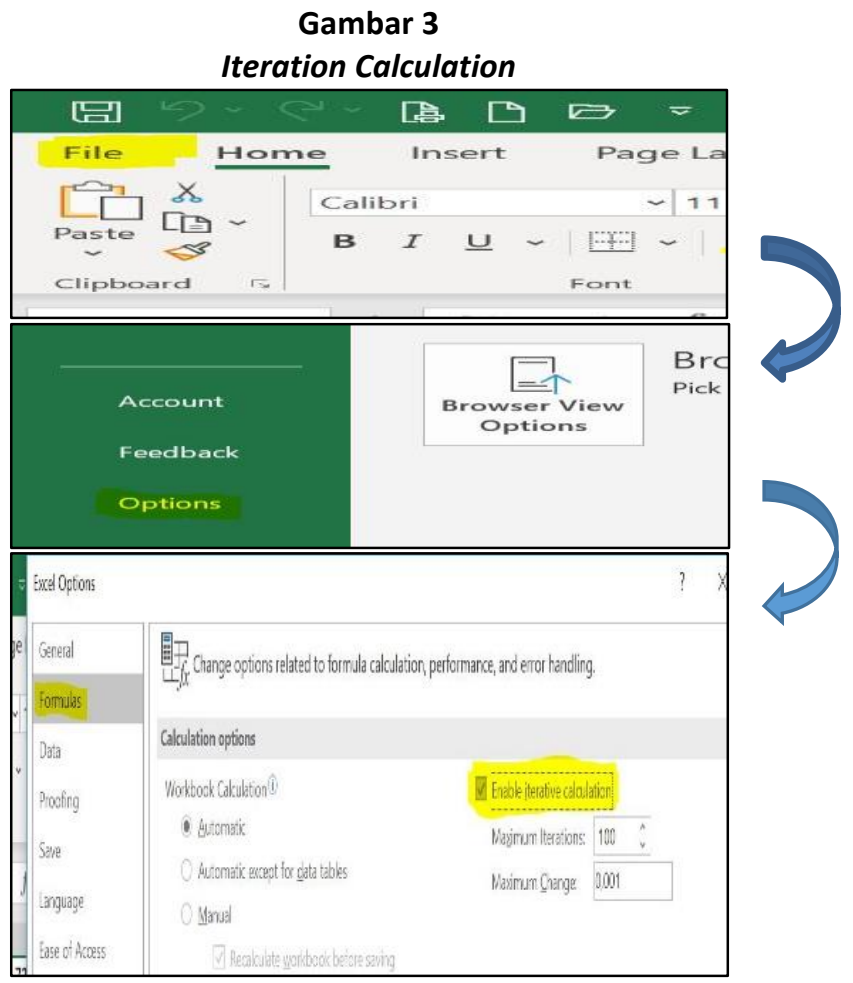

Setelah mengaktifkan fitur iteration calculation, maka kita bisa membuat rumus tunjangan PPh sama dengan PPh Pasal 21 terutang setahun, seperti contoh dibawah ini:

Gambar 4

Rumus Perhitungan Gross-up

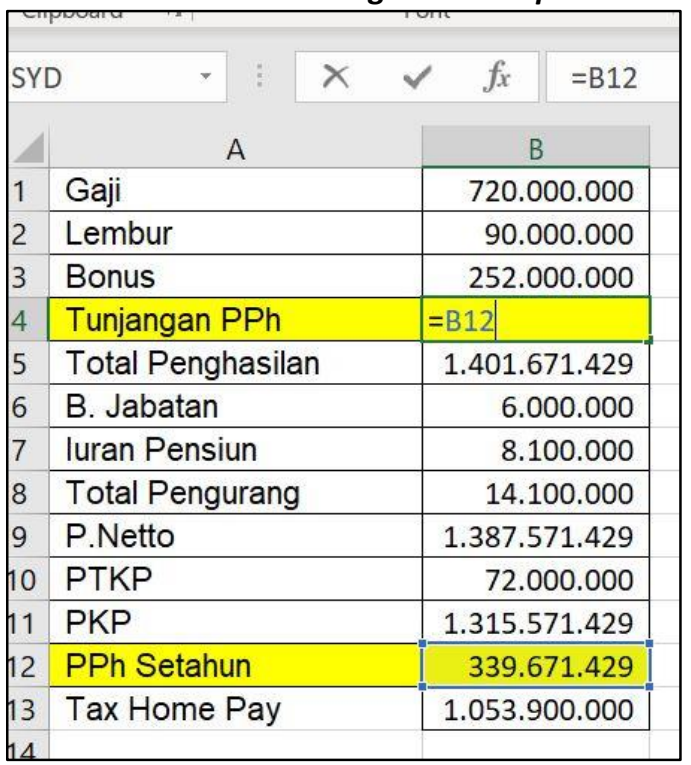


Hasil dari rumus perhitungan PPh Pasal 21 dengan metode gross-up seperti Gambar 4 akan mendapatkan hasil sebagai berikut:

Gambar 5

Hasil Perhitungan Gross-up

\begin{tabular}{|c|l|r|}
\hline \multicolumn{2}{|c|}{ Clipboard A } & \multicolumn{2}{|c|}{$f_{x}$} & $=$ B12 \\
\hline B4 & \multicolumn{1}{|c|}{ A } & \multicolumn{1}{c|}{ B } \\
\hline 1 & Gaji & 720.000 .000 \\
\hline 2 & Lembur & 90.000 .000 \\
\hline 3 & Bonus & 252.000 .000 \\
\hline 4 & Tunjangan PPh & 339.671 .429 \\
\hline 5 & Total Penghasilan & 1.401 .671 .429 \\
\hline 6 & B. Jabatan & 6.000 .000 \\
\hline 7 & luran Pensiun & 8.100 .000 \\
\hline 8 & Total Pengurang & 14.100 .000 \\
\hline 9 & P.Netto & 1.387 .571 .429 \\
\hline 10 & PTKP & 72.000 .000 \\
\hline 11 & PKP & 1.315 .571 .429 \\
\hline 12 & PPh Setahun & 339.671 .429 \\
\hline 13 & Tax Home Pay & 1.053 .900 .000 \\
\hline
\end{tabular}

Berdasarkan Gambar 5, dapat terlihat bahwa jumlah tunjangan PPh sama dengan PPh setahun. Dimana hasil perhitungan PPh setahun, menjadi sumber penjumlahan dalam perhitungan PPh Setahun, dengan nilai yang sama yaitu Rp339.671.429,00. Dengan bantuan fitur ini, perhitungan massal PPh Pasal 21 Pegawai Tetap dapat dilakukan menggunakan aplikasi Ms Excel. Sehingga memudahkan WP dalam melakukan kewajiban perhitungan PPh Pasal 21 melalui metode impor data yang akan dijelaskan kemudian.

\subsection{Hasil Analisis Perbandingan Metode Perhitungan PPh Pasal 21}

Di dalam menganalisa perbandingan metode gross-up dengan metode lainnya, peneliti akan melakukan perhitungan PPh Pasal 21 dengan menggunakan metode yang berbeda. Tujuan dari pengunaan metode ini adalah untuk menunjukan apakah perencanaan pajak yang akan dibuat oleh WP dapat optimal. Dalam melakukan analisis, penulis akan menggukan simulasi atas penghasilan pada lapisan tarif PPh OP yang sudah melebihi tarif PPh Badan dan di bawah tarif PPh Badan. Dalam hal jurnal ini akan menggunakan lapisan tarif $30 \%$ dan $15 \%$.

Pemilihan kedua jenis lapisan tarif bertujuan untuk melihat sampai sejauh mana perencanaan pajak dapat berjalan maksimal. Hal ini dikarenakan PPh Pasal 21 berhubungan dengan biaya gaji yang berimbas kepada laba kena pajak WP. Sehingga semakin tinggi biaya gaji maka PPh
Pasal 21 akan semakin tinggi. Sebaliknya semakin tinggi biaya gaji maka laba kena pajak semakin rendah. Lebih jauh, dengan adanya perbedaan tarif PPh Pasal 21 dengan tarif PPh Badan maka pemilihan simulasi penghasilan akan menggambarkan keuntungan dan kerugian penggunaan metode perhitungan PPh Pasal 21.

Seperti yang telah dibahas pada metode penelitian, jurnal ini akan menggunakan tiga metode perhitungan. Setiap metode perhitungan akan menggunakan penghasilan yang berada di lapisan tarif pajak untuk orang pribadi yang lebih besar dan lebih kecil dari tarif PPh Badan yaitu $25 \%$. Berikut adalah simulasi dari perhitungan dengan metode yang berbeda.

\subsubsection{Metode Gross-up}

Sebagai bahan variabel acuan, perhitungan PPh Pasal 21 untuk setiap lapisan tarif pajak dengan metode ini adalah sebagai berikut:

a. Simulasi perhitungan PPh Pasal 21 untuk penghasilan yang dikenakan sampai dengan lapisan tarif $35 \%$ adalah sepeti contoh berikut:

\begin{tabular}{|l|r|}
\hline Gaji & 720.000 .000 \\
\hline Lembur & 90.000 .000 \\
\hline Bonus & 252.000 .000 \\
\hline Tunjangan PPh & 339.671 .429 \\
\hline Total Penghasilan & 1.401 .671 .429 \\
\hline B. Jabatan & 6.000 .000 \\
\hline luran Pensiun & 8.100 .000 \\
\hline Total Pengurang & 14.100 .000 \\
\hline P.Netto & 1.387 .571 .429 \\
\hline PTKP & 72.000 .000 \\
\hline PKP & 1.315 .571 .429 \\
\hline PPh Setahun & 339.671 .429 \\
\hline Tax Home Pay & 1.053 .900 .000 \\
\hline
\end{tabular}

Dari perhitungan diatas, PPh Pasal 21 terutang menjadi tunjangan PPh. Sehingga terjadi penambahan penghasilan sebesar Rp339.671.429,00. Atas penghasilan tersebut dikalikan tarif pajak tertinggi yaitu 35\%, karena sudah masuk kedalam lapisan tarif pajak tersebut. Sehingga tambahan pajak yang dibayar adalah Rp339.671.429,00 X 35\% = Rp118.885.000,00. Kebalikannya, dengan adanya tunjangan PPh maka biaya pengurang laba kena pajak bertambah. Sehingga pajak yang dibayar perusahaan berkurang sebesar Rp339.671.429,00 X 25\% = Rp84.917.857,00. Dari kedua perhitungan tersebut, maka dapat terlihat WP akan mengalami kerugian, karena jumlah pajak yang dibayar lebih besar daripada penghematan pajak yang didapat. Maka metode ini, apabila diterapkan pada penghasilan yang masuk lapisan tarif pajak $35 \%$, tidak maksimal. Namun demikian tax home pay 
dari pegawai yang bersangkutan menjadi lebih besar karena hanya dipotong iuran pensiun dan tidak dipotong penghasilannya untuk membayar pajak.

b. Simulasi perhitungan PPh Pasal 21 untuk penghasilan yang dikenakan sampai dengan lapisan tarif $15 \%$ adalah seperti contoh berikut:

\begin{tabular}{|l|r|}
\hline Gaji & 266.000 .000 \\
\hline Lembur & 33.250 .000 \\
\hline Bonus & 93.100 .000 \\
\hline Tunjangan PPh & 63.785 .833 \\
\hline Total Penghasilan & 456.135 .833 \\
\hline B. Jabatan & 6.000 .000 \\
\hline luran Pensiun & 2.992 .500 \\
\hline Total Pengurang & 8.992 .500 \\
\hline P.Netto & 447.143 .333 \\
\hline PTKP & 72.000 .000 \\
\hline PKP & 375.143 .333 \\
\hline PPh Setahun & 63.785 .833 \\
\hline Tax Home Pay & 389.357 .500 \\
\hline
\end{tabular}

Berdasarkan perhitungan tersebut, penambahan PPh Pasal 21 yang dibayar meningkat menjadi Rp63.785.833,00 X 15\% = Rp9.567.875,00. Sedangkan pengurangan PPh Badan sebesar Rp63.785.833,00 X 25\% = Rp15.946.458,00. Melihat hasil perhitungan ini, pada lapisan tarif ini WP mendapat keuntungan penghematan pajak. Hal ini dikarenakan penghematan lebih besar dari penambahan pajak yang dibayar. Sedangkan untuk pegawai yang bersangkutan, tax home pay yang didapat juga lebih besar, karena tidak dipotong pajak.

\subsubsection{Metode Gross}

Berikut adalah simulasi perhitungan PPh Pasal 21 menggunakan metode gross:

a. Simulasi perhitungan PPh Pasal 21 untuk penghasilan yang dikenakan sampai dengan lapisan tarif $35 \%$ adalah sepeti contoh berikut:

\begin{tabular}{|l|r|}
\hline Gaji & 720.000 .000 \\
\hline Lembur & 90.000 .000 \\
\hline Bonus & 252.000 .000 \\
\hline Tunjangan PPh & - \\
\hline Total Penghasilan & 1.062 .000 .000 \\
\hline B. Jabatan & 6.000 .000 \\
\hline luran Pensiun & 8.100 .000 \\
\hline Total Pengurang & 14.100 .000 \\
\hline P.Netto & 1.047 .900 .000 \\
\hline PTKP & 72.000 .000 \\
\hline PKP & 975.900 .000 \\
\hline PPh Setahun & 237.770 .000 \\
\hline Tax Home Pay & 816.130 .000 \\
\hline
\end{tabular}

Dari perhitungan tersebut, dapat diketahui bahwa bagi WP tidak berpengaruh apapun. Hal ini dikarenakan tidak ada tunjangan tambahan yang harus ditanggung oleh WP. Namun berbeda halnya bagi pegawai yang bersangkutan. Metode ini merugikan karyawan karena tax home pay-nya berkurang untuk membayar iuran pensiun dan PPh Pasal 21 (Tax home pay $=$ Total Penghasilan - Iuran Pensiun PPh Setahun).

b. Simulasi perhitungan PPh Pasal 21 untuk penghasilan yang dikenakan sampai dengan lapisan tarif $35 \%$ adalah sepeti contoh berikut:

\begin{tabular}{|l|r|}
\hline Gaji & 266.000 .000 \\
\hline Lembur & 33.250 .000 \\
\hline Bonus & 93.100 .000 \\
\hline Tunjangan PPh & - \\
\hline Total Penghasilan & 392.350 .000 \\
\hline B. Jabatan & 6.000 .000 \\
\hline luran Pensiun & 2.992 .500 \\
\hline Total Pengurang & 8.992 .500 \\
\hline P.Netto & 383.357 .500 \\
\hline PTKP & 72.000 .000 \\
\hline PKP & 311.357 .500 \\
\hline PPh Setahun & 47.839 .375 \\
\hline Tax Home Pay & 341.518 .125 \\
\hline
\end{tabular}

Sama halnya dengan lapisan tarif 35\%, pada lapisan tarif ini pun tidak berpengaruh kepada WP. Hal ini disebabkan PPh Pasal 21 yang terutang dibayar oleh pegawai. Sehingga dapat disimpulkan untuk metode ini tidak berpengaruh kepada WP, tetapi mengurangi tax home pay pegawai yang bersangkutan.

\subsubsection{Metode Net}

Berikut adalah simulasi perhitungan PPh Pasal 21 menggunakan metode Net:

a. Simulasi perhitungan PPh Pasal 21 untuk penghasilan yang dikenakan sampai dengan lapisan tarif $35 \%$ adalah sepeti contoh berikut:

\begin{tabular}{|l|r|}
\hline Gaji & 720.000 .000 \\
\hline Lembur & 90.000 .000 \\
\hline Bonus & 252.000 .000 \\
\hline Tunjangan PPh & - \\
\hline Total Penghasilan & 1.062 .000 .000 \\
\hline B. Jabatan & 6.000 .000 \\
\hline luran Pensiun & 8.100 .000 \\
\hline Total Pengurang & 14.100 .000 \\
\hline P.Netto & 1.047 .900 .000 \\
\hline PTKP & 72.000 .000 \\
\hline PKP & 975.900 .000 \\
\hline PPh Setahun & 237.770 .000 \\
\hline PPh Ditanggung Perusahaan & 237.770 .000 \\
\hline Tax Home Pay & 1.053 .900 .000 \\
\hline
\end{tabular}

Dari perhitungan tersebut, didapatkan informasi bahwa tax home pay yang didapat oleh pegawai menjadi meningkat sama seperti metode gross-up. Akan tetapi bagi WP hal ini merugikan, karena selain harus menanggung PPh Pasal 21 pegawai, biaya tersebut tidak dapat mengurangi laba kena pajak. Sehingga tidak maksimal apabila digunakan untuk 
perencanaan pajak. Akan tetapi hal ini akan memotivasi pegawai untuk bekerja lebih baik, karena penghasilan yang diterima sudah bersih dari pajak.

b. Simulasi perhitungan PPh Pasal 21 untuk penghasilan yang dikenakan sampai dengan lapisan tarif $15 \%$ adalah sepeti contoh berikut:

\begin{tabular}{|l|r|}
\hline Gaji & 720.000 .000 \\
\hline Lembur & 90.000 .000 \\
\hline Bonus & 252.000 .000 \\
\hline Tunjangan PPh & - \\
\hline Total Penghasilan & 1.062 .000 .000 \\
\hline B. Jabatan & 6.000 .000 \\
\hline luran Pensiun & 8.100 .000 \\
\hline Total Pengurang & 14.100 .000 \\
\hline P.Netto & 1.047 .900 .000 \\
\hline PTKP & 72.000 .000 \\
\hline PKP & 975.900 .000 \\
\hline PPh Setahun & 237.770 .000 \\
\hline PPh Ditanggung Perusahaan & 237.770 .000 \\
\hline Tax Home Pay & 1.053 .900 .000 \\
\hline
\end{tabular}

Berdasarkan perhitungan tersebut, semakin kecil PPh Pasal 21 yang dibayar, WP semakin berkurang kerugiannya dalam menanggung PPh Pasal 21 yang dibayar.

\subsection{Pemindahan Data PPh Pasal 21 ke e-SPT Melalui File CSV}

Untuk dapat memindahkan data PPh Pasal 21 yang dimiliki oleh WP kedalam e-SPT PPh Pasal $21 / 26$, diperlukan file csv. File contoh ini dapat diperoleh pada folder instalasi e-SPT PPh Pasal 21/26. Pada simulasi ini, folder instalasi ada pada: D:\DJP\dokumentasi\csv format\contoh csv 1721 bp_A1.csv. Untuk ilustrasi dapat diperlihatkan pada gambar berikut:

\section{Gambar 6} Letak File CSV Contoh

\begin{tabular}{|c|c|c|c|c|}
\hline \multicolumn{5}{|c|}{ This PC > DATA (D: $>$ > DJP > dokumentasi > Csv format > contoh CSV } \\
\hline & Name & Date modified & Type & Size \\
\hline 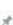 & (3) 1721_bp_A1 & $25 / 02 / 201415,20$ & Mirrosoft Excel Com.. & $1 \mathrm{KE}$ \\
\hline & (3) 1721_bp_A2 & $25 / 02 / 201415.20$ & Microsoft Excel Com.... & $1 \mathrm{Kt}$ \\
\hline 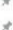 & 19. 1721_bp_final & $25 / 02 / 201415,20$ & Micosoft txcel Com...- & $1 \mathrm{kt}$ \\
\hline * & (a) 1721__p_tidak_final & $25 / 02 / 201415.20$ & Mirososoft Exel Com... & $1 \mathrm{kt}$ \\
\hline * & (8) 1721__bulanan & $25 / 02 / 201415.20$ & Mirosott Excol Com... & $1 \mathrm{~KB}$ \\
\hline & (3) 1721 _refpartner & $25 / 02 / 201415.20$ & Micosoft Exxal Com_. & $1 \mathrm{Kg}$ \\
\hline & (19) 1721 refpegawaiA1 & $25 / 02 / 201415.20$ & Mirososoft Exxel Com... & $1 \mathrm{~kg}$ \\
\hline & b. 1721 retpegawaiA? & $25 / 02 / 201415,20$ & Mirosolt Excel Com..... & $1 \mathrm{Kk}$ \\
\hline
\end{tabular}

File contoh apabil dibuka dengan aplikasi Notepad maka akan berbentu seperti ini:

\section{Gambar 7}

Struktur File CSV

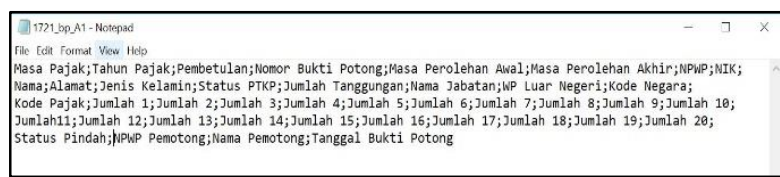

Struktur file csv contoh tersebut dapat dibuka melalui aplikasi Ms Excel untuk diisi datanya sesuai yang dimiliki oleh WP.

Setelah file csv diisi datanya oleh WP melalui aplikasi Ms Excel, selanjutnya dapat disimpan. Ilustrasi file csv yang sudah diisi dapat dilihat pada gambar berikut ini:

\section{Gambar 8}

Tampilan File CSV Pada Ms Excel

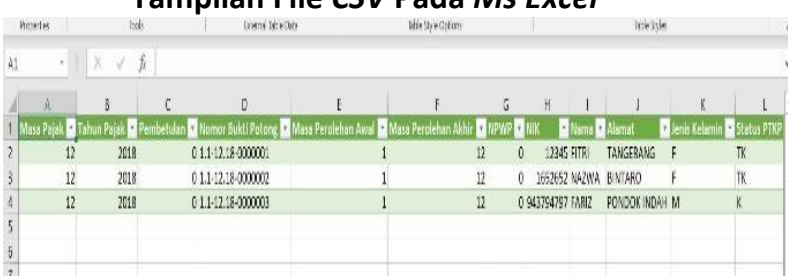

Selanjutnya file yg sudah diisi dan disimpan akan kita masukan kedalam aplikasi e-SPT melalui mekanisme import.

Untuk mengimpor hasil isiian file csv yang sudah diisi, pertama-tama aplikasi e-SPT dibuka. Kemudian setelah dibuat SPT Masa yang akan dilaporkan, dalam hal ini SPT Masa Desember, buka tab csv dan pilih impor. Dalam menu impor akan ada pilihan Bukti Potong, dan dalam Bukti Potong pilih A1. Secara ilustrasi dapat dilihat sebagai berikut:

\section{Gambar 9}

Buka Menu Impor CSV

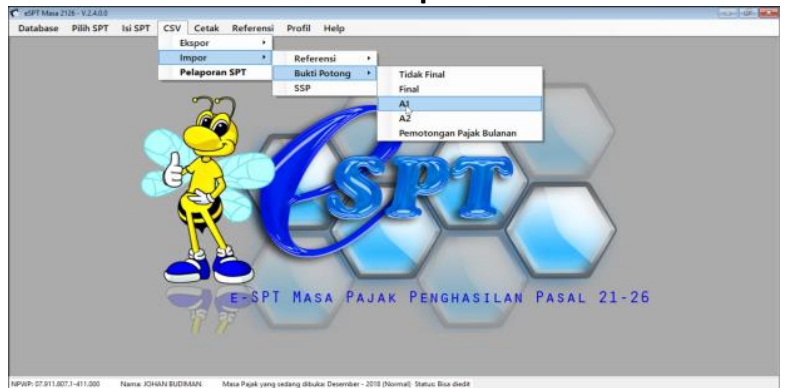

Setelah dibuka menu tersebut, selanjutnya akan muncul jendela baru. Dalam jendela tersebut pilih buka file, dan cari dimana file tersebut disimpan. Urutan ilustrasinya sebagai berikut:

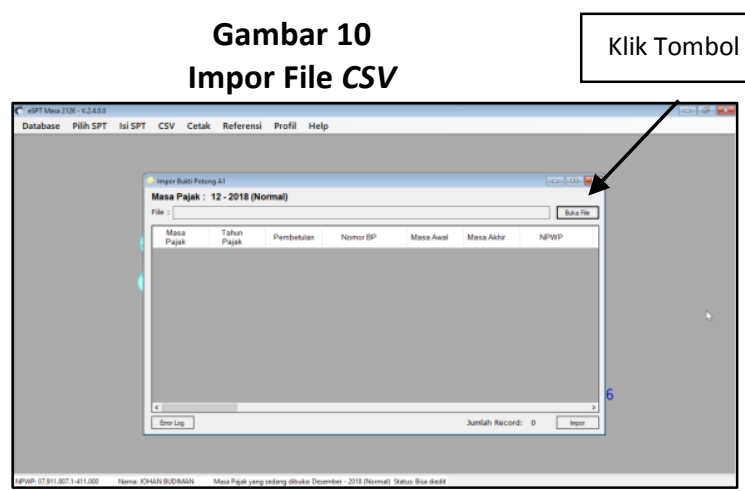




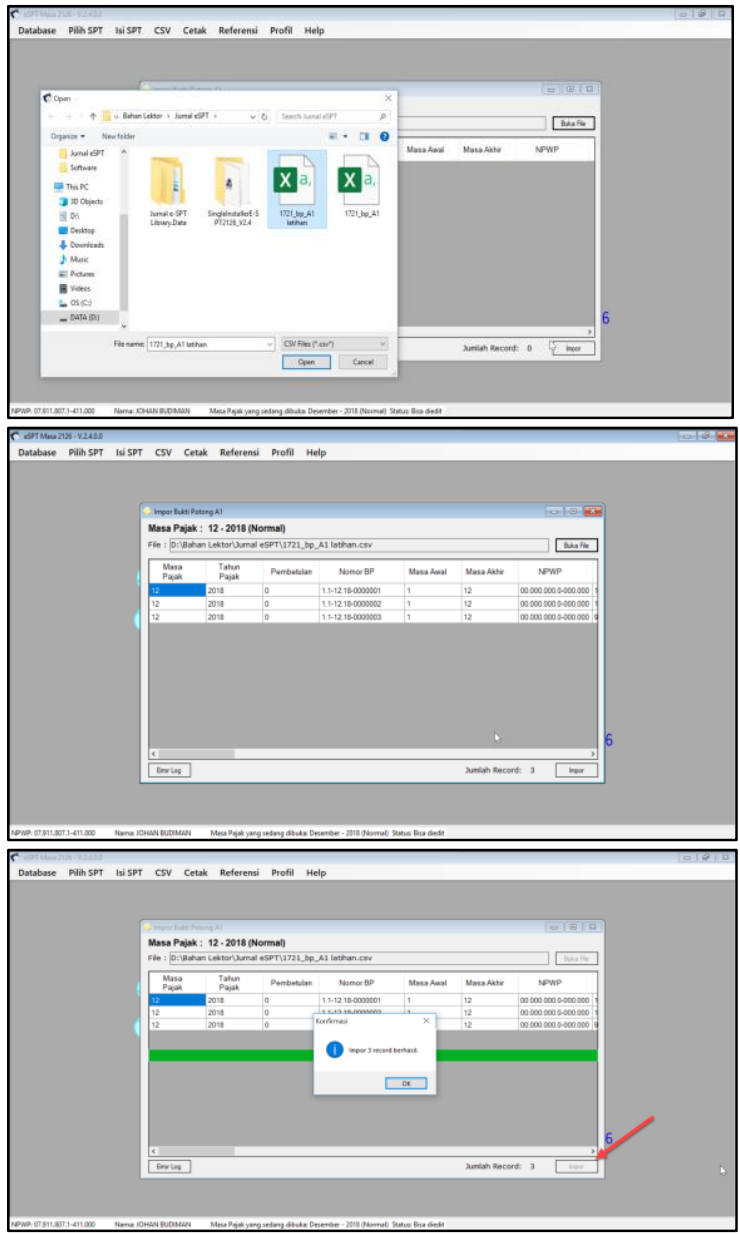

Apabila berhasil akan ada jendela popup yang menginformasikan, impor data berhasil. Dengan berhasilnya impor tersebut, maka proses pemindahan data bukti potong pegawai tetap dengan menggunakan metode gross-up telah selesai.

\section{KESIMPULAN}

Berdasarkan pembahasan permasalahan dalam penelitian ini dapat dijabarkan bahwa penggunaan metode perhitungan gross-up dengan menggunakan aplikasi Ms Excel dapat dilakukan. Hal ini dikarenakan tersedianya fitur iterative calculation pada aplikasi Ms Excel. Sehingga memudahkan WP dalam melakukan perhitungan metode gross-up.

Pengujian komparasi atas metode perhitungan PPh Pasal 21 menunjukan bahwa metode gross-up hanya akan memberikan perencanaan pajak yang baik, apabila diterapkan kepada pegawai yang berada pada lapisan tarif dibawah tarif PPh Badan. Sebaliknya apabila diterapkan pada pegawai yang memiliki penghasilan pada lapisan tertinggi, akan memberikan kerugian kepada WP. Namun demikian pemberian tunjangan pajak atau pajak yang ditanggung pemberi kerja, memberikan keuntungan bagi karyawan, karena penghasilannya tidak dikurangi oleh PPh Pasal 21. Hal ini dapat menimbulkan motivasi pegawai untuk bekerja lebih maksimal.

Pemberian simulasi penggunaan data csv, diharapkan membantu WP dalam menjalankan kewajiban perpajakannya. Minimal memberikan gambaran, cara mudah memindahkan data dari data Ms Excel milik WP kedalam aplikasi e-SPT.

\section{IMPLIKASI DAN KETERBATASAN}

Jurnal ini diharapkan mampu menambah implikasi atas penelitian penggunaan metode Gross-up pada perhitungan PPh Pasal 21. Selain itu juga penelitian ini diharapkan membantu WP dalam menjalankan kewajiban perpajakannya terutama kewajiban pengisian e-SPT. Penelitian ini juga diharapkan dapat membantu DJP dalam mensosialisasikan penggunaan aplikasi e-SPT PPh Pasal 21/26.

Penelitian ini mempunyai beberapa keterbatasan dalam penulisannya. Antara lain keterbatasan yang kemungkinkan menimbulkan ketidakakuratan pada hasil penelitian antara lain :

1. Penulisan ini hanya menggunakan data simulasi yang belum teruji keakuratannya. Penulis tidak menggunakan data WP yang real sebagai bahan penelitian;

2. Data sampel yang digunakan hanya dijalankan pada aplikasi Microsoft Office sederhana, yang memungkinkan ditemukannya cara baru yang lebih effisien;

3. Penelitian ini juga hanya memberikan panduan yang bersifat edukasi, sehingga Analisa yang bersifat ilmiah dapat terus dikembangkan.

\section{DAFTAR PUSTAKA (REFERENCES)}

Arham, M. I. (2016). Analisis Perencanaan Pajak Untuk PPh Pasal 21 Pada PT. Pegadaian (Persero) Cabang Tuminting. Jurnal EMBA: Jurnal Riset Ekonomi, Manajemen, Bisnis dan Akuntansi, 4(1).

Ashriana, A. N. (2017). Analisa Perhitungan PPh 21 dengan Menggunakan Metode Gross Up di CV. MUSTIKA Mojokerto. JEBDEER: Journal of Entrepreneurship, Business Development and Economic Educations Research, 1(1), 45-56.

Direktorat Jenderal Pajak. (2019). Halaman Aplikasi Perpajakan. Retrieved from https://portal.pajak.go.id/id/aplikasi-page

Farida, I., Alfian, M., \& Cempaka, T. S. (2016). Analisis Perencanaan Pajak Atas PPh Pasal 
21 yang Ditanggung Institusi Sebelum dan Sesudah Penerapan Metode Gross Up Pada Politeknik Harapan Bersama Tegal. Politeknik Negeri Jakarta, hal 1, 5.

Irawan, H. P., \& Farahmita, A. (2012). Pengaruh kompensasi manajemen dan corporate governance terhadap manajemen pajak perusahaan. Skripsi, Depok: Universitas Indonesia.

KBBI. (2019). Arti Kata "panduan" Makna Pengertian dan Definisi. Retrieved from https://artikbbi.com/panduan/

Kementerian Keuangan. (2019). Aplikasi Elektronik $e$-SPT Orang Pribadi. Retrieved from https://www.kemenkeu.go.id/page/aplik asi-elektronik-e-spt-orang-pribadi/

Microsoft. (2019). Change formula recalculation, iteration, or precision in Excel. Retrieved from https://support.office.com/enus/article/change-formula-recalculationiteration-or-precision-in-excel-73fc7dac91cf-4d36-86e8-67124f6bcce4

Nabilah, N. N. (2016). Analisis Penerapan Perencanaan Pajak PPh 21 Sebagai Upaya Penghematan Beban Pajak Penghasilan Badan (Studi Kasus Pada PT Z). Jurnal Mahasiswa Perpajakan, 8(1).

Peraturan Direktur Jenderal Pajak Nomor PER16/PJ/2016 Tentang Pedoman Teknis Tata Cara Pemotongan, Penyetoran dan Pelaporan Pajak Penghasilan Pasal 21 dan/atau Pajak Penghasilan Pasal 26 Sehubungan dengan Pekerjaan, Jasa, dan Kegiatan Orang Pribadi, PER-16/PJ/2016 C.F.R. (2016).

Peraturan Menteri Keuangan Nomor 9 Tahun 2018, PMK-9/PMK.03/2018 C.F.R. (2018).

Pohan, C. A. (2013). Manajemen Perpajakan Strategi Perencanaan Pajak dan Bisnis. Gramedia Pustaka Utama, Jakarta.

Sahilatua, P. F., \& Noviari, N. (2013). Penerapan Perencanaan Pajak Penghasilan Pasal 21 Sebagai Strategi Penghematan Pembayaran Pajak. E-Jurnal Akuntansi, 231-250.

Solichin, A. (2010). MySQL5: Dari Pemula Hingga Mahir: Achmad Solichin.

Susanta, G., \& Sutjahjo, H. (2007). Akankah Indonesia tenggelam akibat pemanasan global? : Niaga Swadaya.

Villanueva, J. (2019). Types of descriptive research. Retrieved from https://www.slideshare.net/jeanniferbvill anueva/types-of-descriptive-research

Vridag, R. V. D. (2016). Analisis Perbandingan Penggunaan Metode Net Basis dan Metode Gross Up dalam Perhitungan Pajak Penghasilan Pasal 21 (PPH Pasal 21) Berupa Gaji dan Tunjangan Karyawan PT. Remenia Satori Tepas Manado. Jurnal EMBA: Jurnal Riset Ekonomi, Manajemen, Bisnis dan Akuntansi, 3(4). 